\title{
ZONES OF DISCRETION AT COMMON LAW
}

\section{James E. Pfander}

\begin{abstract}
Long controversial, the doctrine of qualified immunity provides a civil liability shield for police officers and other executive branch officials. Scholars have questioned the doctrine, in part on the basis that it lacks support in the common law rules of official liability that were in place in the nineteenth century when Section 1983 became law. In a recently published article, Scott Keller defends the doctrine's legality by arguing that the common law did indeed recognize forms of qualified immunity.

This Essay suggests that the authorities on which Keller relies comprise a body of administrative law, defining zones of official discretion, rather than a body of qualified immunity law. Many of the doctrines Keller identifies operate much the way Chief Justice Marshall's account of judicial review operated in Marbury v. Madison. Chief Justice Marshall acknowledged that matters lawfully assigned to the discretion of the executive branch were beyond the scope of judicial review. But where an official's lawful discretion ended and legal boundaries were transgressed, the common law was available (indeed obliged, according to Chief Justice Marshall) to supply a remedy. In much of what Keller points to, common law courts were deferring to executive action taken within the zones of their lawful discretion. But the common law did not confer a qualified immunity when executive officials transgressed those boundaries and violated protected rights.
\end{abstract}

AUTHOR-Owen L. Coon Professor of Law, Northwestern University Pritzker School of Law. Thanks to Will Baude, Henry Monaghan, Jide Nzelibe, Alex Reinert, and Joanna Schwartz for thoughtful and comprehensive comments, suggestions, and spreadsheets. Thanks to HanByul Chang and the editors of Northwestern Law Review Online for close reads and excellent editorial suggestions. 


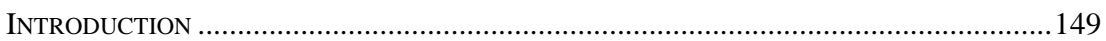

I. ReEXAMINING THE Role OF Discretion AT COMMON LAW ...................................151

A. Government Accountability: A Primer........................................................... 152

B. The Role of Discretion and the Ultra Vires Principle ................................... 157

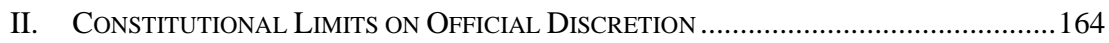

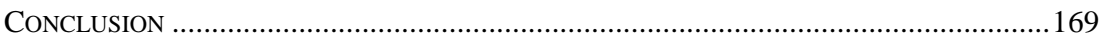

\section{INTRODUCTION}

A controversial judge-made doctrine, qualified immunity bars the award of damages to victims of constitutional wrongs unless the defendant government officials violated "clearly established law." The doctrine has come under renewed scrutiny since the killing of George Floyd. ${ }^{2}$ Scholars have long questioned the policy justifications for the doctrine, arguing that qualified immunity prevents deserving victims from securing redress and also, in practice, fails to protect officers through the promised pretrial dismissal of dubious claims. ${ }^{3}$ Others have expressed doubts as to the legal foundations of the doctrine, pointing out that the common law of official liability in the nineteenth century did not incorporate rules of qualified immunity. ${ }^{4}$ Such findings cast doubt on the Supreme Court's conclusion that Congress impliedly incorporated qualified immunity doctrines from the common law by adopting the precursor to 42 U.S.C. $\S 1983$ in 1871 as a statutory framework for constitutional enforcement against state actors. ${ }^{5}$

Scott Keller, a founding partner of the law firm Lehotsky Keller LLP and the former solicitor general of Texas, argues in an important new article that scholars debating the legitimacy of modern immunity doctrines have

\footnotetext{
1 Harlow v. Fitzgerald, 457 U.S. 800, 818 (1982) (specifying that officers are to be liable for constitutional torts only where they violate clearly established law). Harlow justified the standard as one needed to facilitate the summary adjudication of frivolous claims and to protect officers from the burden of unjustifiable trials. Id. at 815-18. Although Harlow articulated the standard in the course of litigation brought against federal actors under the Bivens doctrine, see Bivens v. Six Unknown Named Agents of Fed. Bureau of Narcotics, 403 U.S. 388, 389 (1971), the Court explained that the same standard would govern suits brought against state actors under 42 U.S.C. § 1983. See Harlow, 457 U.S. at 818 n.30.

2 See Nathaniel Sobel, What Is Qualified Immunity, and What Does It Have to Do with Police Reform?, LAWFARE (June 6, 2020, 12:16 PM), https://www.lawfareblog.com/what-qualified-immunityand-what-does-it-have-do-police-reform [https://perma.cc/YAW5-6HSJ].

3 See Joanna C. Schwartz, How Qualified Immunity Fails, 127 YALE L.J. 2, 48 (2017) (finding that cases are rarely dismissed before discovery or trial on qualified immunity grounds, the very elements of litigation from which qualified immunity is intended to protect officers). The doctrine does, however, increase litigation costs and may deter injured persons from filing suit in the first place. Id. at 62 .

${ }^{4}$ William Baude, Is Qualified Immunity Unlawful?, 106 CALIF. L. REV. 45, 55-56 (2018).

5 See Pierson v. Ray, 386 U.S. 547, 554-55, 557 (1967).
} 
overlooked common law precursors from the nineteenth century. ${ }^{6}$ According to Keller, these nineteenth-century doctrines provide the missing common law backdrop and help answer critics who have questioned the legal basis for immunity's incorporation into modern civil rights law. ${ }^{7}$ In the course of his work, Keller identifies leading treatises from the latter third of the century and reminds us of the value of paying close attention to the past as we work to make sense of the present.

This Essay will argue that in cataloging common law deference to some actions taken in good faith by executive branch officials, Keller has identified not a body of immunity law that shields official actors from liability when they transgress constitutional boundaries. Rather, he has identified a body of law best characterized today as administrative discretion. The doctrines Keller identifies operate much the way Chief Justice Marshall's account of judicial review of executive actions operated in Marbury v. Madison. ${ }^{8}$ Chief Justice Marshall acknowledged that matters lawfully assigned to the discretion of the executive branch were beyond the scope of judicial review. ${ }^{9}$ Similarly, the common law occasionally incorporated notions of official good faith into the liability rule. But where an official's lawful discretion ended and legal boundaries were transgressed, the common law was available (indeed obliged, according to Chief Justice Marshall) to supply a remedy.$^{10}$ Because the Constitution operated to limit official discretion, there was no room for arguments about good faith when executive officials violated the Constitution.

Part I of the Essay describes the manner in which common law courts deferred to the acts of executive officials within the zone of discretion conferred by the legislature. Government regulation, even in the nineteenth century, sometimes cast uncompensated burdens on regulated parties. But individuals had no right to recover for the cost of complying with government regulations so long as officials stayed within the zone of discretion legislatures had lawfully conferred. Like modern courts applying

\footnotetext{
${ }^{6}$ Scott A. Keller, Qualified and Absolute Immunity at Common Law, 73 STAN. L. REV. 1337, 1344 45 (2021).

7 See id. at 1344 n.34 (citing works refuted by his new account of the common law pedigree of qualified immunity). Keller cites a number of decisions from the last third of the nineteenth century; this brief reply will concentrate on leading cases from before the Civil War, seeing those as the more relevant backdrop to an 1871 enactment. For an important response to Keller and a more complete evaluation of his authorities, see William Baude, Is Quasi-Judicial Immunity Qualified Immunity?, 73 STAN. L. REV. ONLINE (forthcoming 2021), https://ssrn.com/abstract=3746068 [https://perma.cc/E3Q6-7FF8] (arguing that Keller identifies a body of quasi-judicial immunity that does not serve as a precursor to, and does not justify, modern qualified immunity law).

8 See 5 U.S. (1 Cranch) 137, 165-66 (1803).

${ }^{9} \mathrm{Id}$. at 166.

${ }^{10}$ See id. at 170.
} 
administrative law, nineteenth-century courts used the concept of discretion to help define lawful executive activity. When officials exceeded the scope of their discretion or committed positive government wrongs, they were held accountable. Contrary to Keller's suggestion, there was no common law immunity - qualified or otherwise - when executive officials violated the law, a conclusion Keller's treatises confirm.

Part II describes the role that constitutional limits played in judicial assessments of the legality of official conduct. Such limits operated much the way statutory limits did - to confine the exercise of lawful discretion. Thus, for example, the Ohio officials who collected a state tax from the Bank of the United States in 1819 could not claim qualified immunity when they relied on an unconstitutional grant of state taxing authority. ${ }^{11}$ The Constitution invalidated the state tax, stripped the officials of their official authority, and left them subject to liability at common law for trespass. ${ }^{12}$ That they doubtless acted in good faith in carrying out the state's directive to seize the bank's assets gave them no immunity from suit. Indeed, as this Essay concludes, Keller fails to establish that common law courts would extend to executive officers acting in good faith a discretionary authority to violate the Constitution.

\section{REEXAMINING THE ROLE OF DISCRETION AT COMMON LAW}

This Part seeks to situate the doctrines on which Keller relies in nineteenth-century common law rules of government accountability. Section A sets the stage by outlining the widespread reliance on common law writs that operated to impose liability on government officials. Some of these remedies operated-like injunctions today-to compel officers to take specified action. Some occasioned entry of judgments for money damages payable by the officer. But no doctrine of qualified immunity shielded executive officers from personal liability; instead, the legislature would protect government officers by providing indemnifying payments to cover the costs of any liability imposed.

Section B draws on the nineteenth-century dispensation to better understand the rules that Keller characterizes as examples of qualified immunity. Much of what Keller points to in nineteenth-century law reflects judicial deference to lawful discretion in the review of official action. When officials enjoyed lawful discretion to act, they did not violate the law. The job of courts was to define the boundaries of that discretion by examining the statutory framework and invalidating official action that exceeded

\footnotetext{
11 See Osborn v. Bank of U.S., 22 U.S. (9 Wheat.) 738, 777-79 (1824).

12 Id. at 869-71.
} 
applicable limits. When the courts upheld official action, they concluded in effect that no law had been violated; qualified immunity played no role in the analysis. ${ }^{13}$ Outside the administrative sphere, when officials committed positive government wrongs by invading individual rights to property or personal liberty, they enjoyed no zone of lawful discretion. Section B concludes with a close reading of the treatises on which Keller relies, showing that they do not recognize any qualified immunity for executive officials.

\section{A. Government Accountability: A Primer}

To understand the rules of government accountability, we begin with the doctrine of sovereign immunity from suit. ${ }^{14}$ The doctrine, though far less immutable than some have suggested, was taken as a fact of life in the early republic; ${ }^{15}$ it meant that individuals who were wronged at the hands of the government could not bring suit against the government itself (except as the legislature so provided). ${ }^{16}$ Immunity appears to have reflected an incongruous American fealty to the English adage that the king can do no wrong; after all, the Americans had broken with the king. ${ }^{17}$ It might be better understood as a reflection of the simple truth that, given the assembly's control of the public purse, any payments from the fisc would require legislative approval. ${ }^{18}$ The common law of accountability thus depended on the availability of suits against officers of the government rather than against the government itself. ${ }^{19}$

Such officer suits were commonly available through the writ system and, depending on the writ chosen, any resulting judgment might direct the officer to perform specific action (on pain of contempt) or to pay money to

13 See Ann Woolhandler, Patterns of Official Immunity and Accountability, 37 CASE W. RSRV. L. REV. 396, 414-19, 422-30 (1987) (discussing the emergence of legality and discretionary models of official liability in the nineteenth century).

${ }^{14}$ See James E. Pfander, Sovereign Immunity and the Right to Petition: Toward a First Amendment Right to Pursue Judicial Claims Against the Government, 91 Nw. U. L. REv. 899, 963-64 (1997).

15 See id. at 939-42 (explaining that during the founding era, seven states-including New York, Pennsylvania, and Virginia - established judicial modes for claims against the government).

16 On the origins of sovereign immunity in England and its "mysteri[ous]" introduction into the United States, where kings and royal prerogatives are unknown, see Edwin M. Borchard, Government Liability in Tort, 34 YALE L.J. 1, 4 (1924).

17 See Louis L. Jaffe, Suits Against Governments and Officers: Sovereign Immunity, 77 HARV. L. REv. 1, 1-19 (1963) (describing Crown immunity under the English dispensation and observing mildly that the Americans had expelled the Crown).

${ }^{18}$ On the importance of Congress's role as master of the purse strings in the recognition of sovereign immunity, see Paul F. Figley \& Jay Tidmarsh, The Appropriations Power and Sovereign Immunity, 107 Mich. L. REV. 1207, 1259 (2009).

19 See Jaffe, supra note 17, at 20-26; Borchard, supra note 16, at 6; Pfander, supra note 14, at 96671. 
the plaintiff. ${ }^{20}$ Consider, for example, the writ of habeas corpus, which commanded the warden to bring a prisoner to court (along with a description of the cause of confinement). ${ }^{21}$ If the court was unsatisfied with the proffered justification of confinement, the prisoner went free. Consider, as well, the prerogative writs of mandamus, certiorari, and prohibition. ${ }^{22}$ (1) Mandamus directed the officer to perform specified ministerial actions required by law; (2) certiorari tested (usually after the fact) whether a board or tribunal had jurisdiction to issue a challenged order or decree and invalidated the action taken outside of the jurisdictional boundaries; (3) prohibition, issued at the outset of a proceeding, barred an inferior judicial body from taking up a dispute over which it lacked authority. ${ }^{23}$ These writs obliged the government to comply with the law by operating on the officers named as defendants. ${ }^{24}$ Such proceedings were not thought to implicate any qualified immunity from suit on the part of the officer or any sovereign immunity from suit on the part of the government. ${ }^{25}$

${ }^{20}$ For reliance on contempt sanctions (or "body attachment," as it was then known) to enforce specific decrees of habeas, mandamus, certiorari, and prohibition, see James E. Pfander \& Jacob P. Wentzel, The Common Law Origins of Ex parte Young, 72 STAN. L. REv. 1269, 1314 \& n.268, 1350 \& n.502, $1351 \&$ n.508 (2020).

${ }^{21}$ On the history of habeas, tracing its origins in England and incorporation into the practices of the United States, see generally AMANDA L. TYLER, HABEAS CORPUS IN WARTIME: From THE TOWER OF LONDON TO GUANTANAMO BAY (2017).

${ }^{22}$ For an overview of the nineteenth-century handling of mandamus, prohibition, and certiorari, see Pfander \& Wentzel, supra note 20, at 1311-18 (collecting authority). For a restatement of those principles, see Wilson v. Mayor of New-York, 1 Abb. Pr. 4, 18-19 (N.Y.C.P. 1854) (describing mandamus as issuing where "a party has a legal right, and there is no other appropriate legal remedy" but noting that mandamus does not lie when "under the particular statute relied upon by the plaintiffs, there [is] a discretion given to the defendants"). A court has described the role of certiorari as "the chief means by which [state courts would] review administrative action" throughout the nineteenth century. Frank J. Goodnow, The Writ of Certiorari, 6 POL. SCI. Q. 493, 493 (1891); see 4 CHARles VINER, A GENERAL ABRIDGMENT OF LAW AND EQUiTY 360-61 (2d ed. 1791); Lawton v. Comm'rs of Highways, 2 Cai. 179, 182 (N.Y. Sup. Ct. 1804). Prohibition was a powerful remedy to stay an improper proceeding, but courts did not necessarily regard it as available to oversee the work of boards and commissions. See Pfander \& Wentzel, supra note 20, at 1317-18, 1317 n.310.

${ }^{23}$ On the origins of the prerogative writs, see S.A. DE SMITH, JUdiCIAL REVIEW OF ADMINISTRATIVE ACTION 584 app. I at 586 (J.M. Evans ed., 4th ed. 1980).

${ }^{24}$ On the effectiveness of contempt sanctions in litigation against the federal government, see Nicholas R. Parrillo, The Endgame of Administrative Law: Governmental Disobedience and the Judicial Contempt Power, 131 Harv. L. Rev. 685, 703, 780 (2018).

25 Under the party-of-record rule, litigation could proceed against officers of the Crown without implicating the Crown's immunity on the theory that it was the Crown itself, acting through the courts, that demanded an accounting from its officials. See generally Pfander \& Wentzel, supra note 20, at 133537. On the accountability of the government officer at common law, see James E. Pfander, Dicey's Nightmare: An Essay on the Rule of Law, 107 CALIF. L. REv. 737, 744-47, 754-56, 762-66 (2019). 
Individuals could also proceed against government officials with writs of trespass, assumpsit, and ejectment. ${ }^{26}$ Trespass provided remedies when the government invaded an individual's common law rights to personal integrity or property ownership. Seizure, arrest, and prosecution could occasion a false imprisonment or malicious prosecution claim; the unauthorized taking of property could lead to a trespass action. ${ }^{27}$ Taxpayers, such as those who imported goods into the United States and were obliged to pay customs duties, could challenge the amount of the collected tax by paying under protest and bringing suit to recover the disputed payment through an assumpsit action against the official collector of the customs. ${ }^{28}$ If the court agreed that the tax was unlawful, it would so decree and award a judgment to "recover back the money so paid." ${ }^{29}$ Common lawsuits could also seek to eject government officials from land owned by the plaintiff. ${ }^{30}$

Executive officials did not enjoy any qualified (or absolute) immunity from such suits. Thus, in Marbury v. Madison, the Court recounted the common law framework for mandamus proceedings and confirmed the absence of any immunity for defendant officials. ${ }^{31}$ Under that framework, the Court characterized Madison's duty to deliver a legally valid commission as nondiscretionary, or ministerial, an act which the law could compel Madison to perform. ${ }^{32}$ Madison could claim no immunity from suit, as the Court explained:

If one of the heads of departments commits any illegal act, under color of his office, by which an individual sustains an injury, it cannot be pretended that his

\footnotetext{
${ }^{26}$ For a summary of the operation of these common law writs, see James E. Pfander \& Andrew G. Borrasso, Public Rights and Article III: Judicial Oversight of Agency Action, 82 Оніо ST. L.J (forthcoming 2021) (manuscript at 20), https://papers.ssrn.com/a=3867839 [https://perma.cc/J639FZAJ].

27 See Little v. Barreme, 6 U.S. (2 Cranch) 170, 176, 179 (1804) (holding a federal officer liable for trespass to allow recovery for seizure of property); Merriam v. Mitchell, 13 Me. 439, 453, 457 (1836) (granting recovery for false imprisonment for arrest and imprisonment on mistaken grounds).

28 See Woolhandler, supra note 13, at $414 \mathrm{n} .87$ (confirming that assumpsit was available to recover taxes paid under protest); Elliott v. Swartwout, 35 U.S. (10 Pet.) 137, 156 (1836) (holding that assumpsit lies to recover back taxes paid under protest).

29 See Wilson v. Mayor of New-York, 1 Abb. Pr. 4, 26-27 (N.Y. C.P. 1854) (citing, among others, Amesbury Woollen \& Cotton Mfg. Co. v. Inhabitants of Amesbury, 17 Mass. (16 Tyng) 461 (1821))

30 See United States v. Lee, 106 U.S. 196, 221, 223 (1882) (authorizing an ejectment suit to oust federal military officials from possession of land that was to become Arlington National Cemetery).

${ }^{31}$ See 5 U.S. (1 Cranch) 137, 163-65, 168-69 (1803).

32 On the distinction between ministerial and discretionary acts for mandamus purposes, see FLOYD R. MeChem, A TREatise ON THE LAW OF Public OfFices AND OFFiCERS $§ 611$ (1890) (explaining that "courts will not undertake to control official discretion or the performance of doubtful or uncertain duties, but where the duty to perform a ministerial act is clearly and imperatively imposed upon such an officer, the courts will enforce its performance by mandamus").
} 
office alone exempts him from being sued in the ordinary mode of proceeding, and being compelled to obey the judgment of the law. ${ }^{33}$

As with mandamus proceedings, so too with suits for damages. Officials who committed positive government wrongs by violating an individual's rights, ${ }^{34}$ such as the illegal capture of the ship in Little $v$. Barreme $^{35}$ or the false arrest of a subordinate for stealing from the U.S. mail in Merriam v. Mitchell, ${ }^{36}$ were subject to personal liability for trespass or false imprisonment. ${ }^{37}$ Captain Little sought to justify his actions by pointing to grants of authority, but the Court concluded that the applicable federal statute had not (and a presidential directive could not have) conferred legal authority. ${ }^{38}$ Similarly, Mitchell was held liable for causing the arrest of a subordinate, despite the fact that Mitchell was carrying out orders from his supervisors to investigate thefts from the mail in Maine. ${ }^{39}$ Both Little and Mitchell argued with some force that they acted in good faith. But both the Supreme Court of the United States (in Little) and the Supreme Court of Maine (in Mitchell) rejected the arguments for a good faith defense. ${ }^{40}$

33 Marbury, 5 U.S. (1 Cranch) at 170.

34 See Woolhandler, supra note 13, at 403 n.31.

35 See Little v. Barreme, 6 U.S. (2 Cranch) 170, 170 (1804).

36 See Merriam v. Mitchell, 13 Me. 439, 439, 444-45, 458 (1836).

37 In both instances, Congress indemnified the defendants, holding them harmless for liability they incurred in the line of duty. See James E. Pfander \& Jonathan L. Hunt, Public Wrongs and Private Bills: Indemnification and Government Accountability in the Early Republic, 85 N.Y.U. L. REV. 1862, 1902 (2010) (describing Little's indemnification); James E. Pfander, Suits Against Officeholders, in THE CAMBRidge Companion to the United States Constitution 360, 361-63 (Karen Orren \& John W. Compton eds., 2018) (describing Mitchell's indemnification).

38 Little, 6 U.S. (2 Cranch) at 177-79.

${ }^{39}$ Merriam, $13 \mathrm{Me}$. at $457-58$.

40 See Little, 6 U.S. (2 Cranch) at 179; Merriam, 13 Me. at 457. Keller argues that Little represents an application of the rule that actions in clear absence of jurisdiction subjected even an officer with some discretionary authority to liability. Keller, supra note 6, at 1353-54. But the Court did not explicitly invoke that clear absence standard in Little, and Chief Justice Marshall's account of his own thinking suggests that the issue resolved in Little was one involving the proper allocation of decision-making authority among the branches of government. Had the Court conferred a good faith immunity in Little, as Chief Justice Marshall suggested, then the claim by the owner of the Flying Fish would run against the U.S. government and would, as Chief Justice Marshall explained, thereby become a "proper subject for negotiation." Little, 6 U.S. (2 Cranch) at 179. Chief Justice Marshall had been Secretary of State under President John Adams during negotiations over congressional payment of compensation to the owners of a British vessel in 1799. See Pfander \& Hunt, supra note 37, at 1894, 1901 n.174. But Jefferson and Madison took the position that the determination of such claims required a judicial decision on legality preliminary to consideration by Congress of the passage of indemnifying legislation. Id. at 1895-1900. Chief Justice Marshall thus acquiesced not in a finding that Little acted in clear absence of jurisdiction but in a conception of the proper role of the courts in passing on questions of legality. Had Chief Justice Marshall and the Court recognized a good faith defense, the federal courts would have no occasion to consider the strict legality of the action and victims of government wrongdoing would have been forced to apply to Congress for the payment of compensation. 
Military officers under orders to arrest civilians during the War of 1812 were similarly held personally liable and denied any good faith exemption from trespass liability. ${ }^{41}$

Courts justified their refusal to recognize any good faith immunity by pointing to the nineteenth-century practice through which legislative assemblies indemnified government officials for liability they incurred for actions taken in the line of duty. ${ }^{42}$ The practice of indemnity was established quite early at the federal level, as Madison and Jefferson worked to secure legislation to pay the damages awarded against naval officials who (like Captain Little) had been held liable for wrongful actions during the QuasiWar with France. ${ }^{43}$ The institutionalization of indemnity practice meant, in effect, that officers had a right to reimbursement from the government for any personal liability imposed by the court, much the way officers then and now were represented in court by attorneys hired by the federal government. ${ }^{44}$ Such a practice did not shield officers from liability and did not prevent the court from reaching the merits. Instead, indemnity neatly shifted the cost of government wrongdoing to the fisc, thereby enabling the courts to adjudicate issues of legality and afford redress to victims of government wrongdoing, free of sovereign immunity, without deference to executive claims of necessity or to arguments about legal uncertainty. Legislatures exercised some discretion in granting indemnity, accepting financial responsibility for some official wrongdoing but refusing to indemnify in situations where the officer had acted outside the line of duty. A study of the practice during the early republic suggests that, like Little and Mitchell, roughly two-thirds of the federal officials held accountable in suits for money secured indemnity from Congress..$^{45}$

41 See Pfander, supra note 25, at 775-76 (describing successful trespass claims against military officers who arrested U.S. citizens for aiding the British during the War of 1812).

42 See Imlay v. Sands, 1 Cai. 566, 567-68, 573 (N.Y. Sup. Ct. 1804) (explaining that the judicial task in such cases was "to pronounce the law as we find it" and to "leave cases of hardship, where any exist, to legislative provision").

43 See Pfander \& Hunt, supra note 37, at 1877-87, 1894-1903 (describing the American interdiction of foreign shipping during the Quasi-War with France and the role of Madison and Jefferson in allocating institutional responsibility as between the courts and the legislature for the adjudication of claims and the grant of indemnity).

${ }^{44}$ On the officer's right to indemnity, see Tracy v. Swartwout, 35 U.S. (10 Pet.) 80, 98-99 (1836) (admitting that application for indemnity might cause some "personal inconvenience" for officers held legally accountable but "no eventual hardship" because "the government in such cases is bound to indemnify the officer"); Cary v. Curtis, 44 U.S. (3 How.) 236, 263 (1845) (describing the government as bound to indemnify for liability incurred under instructions). In the personal liability suits that grew out of the Quasi-War, naval officers were typically represented in court by government lawyers. See Pfander \& Hunt, supra note 37, at 1897-1901 (recounting the litigation against officers Maley and Murray).

45 See Pfander \& Hunt, supra note 37, at 1867. 
The nineteenth-century system of government accountability thus made a distinctive allocation of authority among the three branches of government, as Justice Story explained in the course of providing redress for maritime torts committed by federal government officials:

It may be fit and proper for the government, in the exercise of the high discretion confided to the executive, for great public purposes, to act on a sudden emergency, or to prevent an irreparable mischief, by summary measures, which are not found in the text of the laws. Such measures are properly matters of state, and if the responsibility is taken, under justifiable circumstances, the Legislature will doubtless apply a proper indemnity. But this Court can only look to the questions, whether the laws have been violated; and if they were, justice demands, that the injured party should receive a suitable redress. ${ }^{46}$

For Justice Story, then, the government will sometimes act in violation of the law. But the courts cannot grant qualified immunity to shield officers from liability; courts must enforce the law. Officers acting in good faith were in need of protection from personal liability, but they were not given a judicial immunity from liability; rather, they were expected to apply to the legislature for indemnity.

\section{B. The Role of Discretion and the Ultra Vires Principle}

Notwithstanding the absence of qualified immunity at common law, courts conducting judicial review of official action recognized zones of official discretion within which officers were free to exercise their best judgment without judicial oversight. One can see these zones of discretion at work in modern treatments of administrative law. Under the ultra vires principle, courts act properly when they invalidate agency action that exceeds legislative boundaries but defer to agency decisions taken within those legislative boundaries. ${ }^{47}$ As it was applied in the nineteenth-century common law world, the ultra vires principle helps explain the scope of review available in suits seeking remedies for official misconduct. Mandamus at common law reached only ministerial matters when the legal duty was clearly defined by law; under this writ, decisions rightly assigned to executive discretion were beyond judicial review. Writs of prohibition were sometimes issued to quasi-judicial boards and commissions. But such writs served only to remedy action in excess of jurisdiction, rather than to review discretionary judgments made within the inferior tribunal's

46 The Apollon, 22 U.S. (9 Wheat.) 362, 366-67 (1824).

47 See Paul Craig, Ultra Vires and the Foundations of Judicial Review, 57 CAMBRIDGE L.J. 63, 64 65 (1998) (describing the ultra vires principle as a way to enforce legislative limits on official action so that, for example, "an institution given power ... to adjudicate on employment matters should not take jurisdiction over non-employment matters"). 
acknowledged authority, and certiorari was thought to provide for direct review of jurisdictional and legal errors but not the lawful exercise of discretion. ${ }^{48}$

Something quite similar to the ultra vires principle also shaped the relief available in suits for money damages against government officials. As we have seen, suits brought in trespass, assumpsit, replevin, and the like triggered an assessment of the legality of official conduct and directed the payment of damages or the proper disposition of property. ${ }^{49}$ But as with specific remedies like mandamus and certiorari, trespass and assumpsit litigation proceeded on the basis that officers who stayed within the boundaries of their legal discretion did not violate positive law. For example, customs officers and other tax collectors were subject to liability in assumpsit if they collected tax payments in violation of law. ${ }^{50}$ But when the law obliged the tax collector to make a discretionary judgment of how much payment was to be collected - such as with a discretionary valuation of the property subject to taxation - and did not supply an obligatory legal standard for making that valuation, assumpsit would not lie to review the valuation decision. ${ }^{51}$ In such cases, the officers did not enjoy qualified immunity; rather, their exercise of discretion within the boundaries legislatively assigned did not violate the law.

In much of the authority Keller highlights in support of his theory that the common law recognized an immunity doctrine, courts were defining lawful zones of executive discretion as conferred by statute rather than creating a common law exemption from liability for those who violated the law. Consider Otis v. Watkins ${ }^{52}$ and Crowell v. McFadon, ${ }^{53}$ two antebellum cases on which Keller relies. ${ }^{54}$ Both cases arose from Jefferson's embargo, legislation that barred U.S. merchants, many located in Federalist New

\footnotetext{
48 See Pfander \& Wentzel, supra note 20, at 1299-1303 (describing the function of the writs of mandamus, certiorari, and prohibition).

49 See supra notes 26-30 and accompanying text.

50 See Wilson v. Mayor of New-York, 1 Abb. Pr. 4, 27 (N.Y. C.P. 1854) (citing, among others, Amesbury Woollen \& Cotton Mfg. Co. v. Inhabitants of Amesbury, 17 Mass. (16 Tyng) 461 (1821)).

${ }^{51}$ See Bartlett v. Kane, 57 U.S. (16 How.) 263, 272-73 (1854) (denying assumpsit to contest the valuation assigned to imported goods). See generally Nicholas R. Parrillo, A Critical Assessment of the Originalist Case Against Administrative Regulatory Power: New Evidence from the Federal Tax on Private Real Estate in the 1790s, 130 YALE L.J. 1288, 1304 (2021) (describing the broad discretion assigned to federal tax assessors, whom Congress charged with assigning a "just and equitable" value for tax purposes to every house and farm in the union).

5213 U.S. (9 Cranch) 339 (1815).

5312 U.S. (8 Cranch) 94 (1814).

54 Keller, supra note 6, at 1368-69.
} 
England, from exporting goods to Great Britain. ${ }^{55}$ Contrary to what Keller suggests, the Court's decision to deny recovery in both cases did not rest on a common law doctrine of qualified immunity. Instead, the Court based its decisions on the language of the statute, which authorized collectors of the customs "to detain any vessel ostensibly bound with a cargo to some other port of the United States, whenever in their opinion the intention is to violate or evade any of the provisions of the acts laying an embargo." ${ }^{56} \mathrm{By}$ virtue of having authorized detention based on the "opinion[s]" of the collectors, the Act was interpreted to confer a zone of discretion on the collector and to bar recovery even when the opinion might be fairly contestable. ${ }^{57}$ Such an interpretation of the Act was not inevitable; Chief Justice Marshall dissented in Otis on the basis that the collector's opinion must be reasonably based on the evidence adduced. ${ }^{58}$ But no one contended that Congress lacked the power to confer such discretion or that such discretion, once lawfully conferred, was subject to judicial override. Nor did anyone contend that the common law, absent the adoption of a statute, would have exempted the officer from liability.

In another case on which Keller relies, ${ }^{59}$ Wilkes v. Dinsman, denial of recovery for the plaintiff was based on a finding that the defendant official had acted within the zone of discretion, placing the action outside of judicial review. ${ }^{60}$ There, a marine came to what he regarded as the end of his enlistment during a voyage Congress had authorized for purposes of "commerce and science." ${ }^{61}$ Concluding that the marine had reenlisted for the duration and had no right to refuse service, the commander had him whipped and imprisoned on shore. ${ }^{62}$ In the suit for damages that followed, the Court drew an explicit analogy to the writ of mandamus in denying recovery. ${ }^{63}$ For the Court, the defendant was best understood as a nonministerial, quasi-

55 On the politics of Jefferson's embargo and its impact on New England, see generally GORDON S. WOOD, EMPIRE OF LIBERTY: A HISTORY OF THE EARLY REPUBLIC, 1789-1815, at 647-58 (2009).

56 Crowell, 12 U.S. (8 Cranch) at 95 (citing Act of April 25, 1808, ch. 66, § 11, 2 Stat. 499, 501); Otis, 13 U.S. (9 Cranch), at 346 (same).

57 See Otis, 13 U.S. (9 Cranch) at 355-56. For evidence that "opinion" was a term of art understood to confer discretion on executive officers, see Kevin Arlyck, Delegation, Administration, and Improvisation, 97 NOTRE DAME L. REV. (forthcoming 2021) (manuscript at 25), https://ssrn.com/abstract=3802760 [https://perma.cc/EH5C-H3YT] (quoting a provision of the Remission Act of 1790 that conferred complete discretion on the Treasury to remit any penalty if in the Secretary's "opinion" the penalty had been incurred without fraudulent intent).

58 See Otis, 13 U.S. (9 Cranch) at 357-58 (Marshall, C.J., dissenting).

59 See Keller, supra note 6, at 1361-63.

6048 U.S. (7 How.) 89, 132 (1849).

61 See id. at 122-23.

62 Id. at 122.

63 Id. at 129. 
judicial officer, whose exercise of discretion in the course of his command was not subject to judicial review. ${ }^{64}$

Hence, while an officer acts within the limits of that discretion, the same law which gives it to him will protect him in the exercise of it. But for acts beyond his jurisdiction, or attended by circumstances of excessive severity, arising from ill-will, a depraved disposition, or vindictive feeling, he can claim no exemption, and should be allowed none under color of his office, however elevated or however humble the victim. ${ }^{65}$

The decision thus followed the common law in reaffirming the judicial role in policing jurisdictional boundaries but leaving officials free to act, without malice, within their zone of discretion. ${ }^{66}$

Discretion, rather than immunity, remained central to the judicial review of official action, even as late as the 1896 decision in Spalding $v$. Vilas ${ }^{67}$ on which Keller relies. ${ }^{68}$ In Spalding, the Court rejected an attempt by an attorney to secure damages for the losses he allegedly suffered due to the implementation of a new policy by the postal service ${ }^{69}$ Carrying out the new policy, the postal official sent circulars to former post office employees, explaining that they were entitled to direct receipt of back pay and were not obligated to retain counsel to secure such payments. ${ }^{70}$ The plaintiff alleged that the circular made it more difficult for him to collect his fees from the postal workers he represented, was defamatory in some respects, and was the product of malice on the defendant's part. ${ }^{71}$ The Court treated the postal official as a quasi-judicial official, operating within a zone of discretion in deciding how best to administer the policy that Congress had specified when it authorized the direct payment of back pay. ${ }^{72}$ Concluding that the official had carried out this policy within the limits of his lawful discretion, the Court rejected the plaintiff's claim. ${ }^{73}$

\footnotetext{
${ }^{64}$ See id. at 129.

$65 I d$. at 130.

${ }^{66}$ Keller ascribes some significance to the role malice played in the common law scheme, comparing it with the good faith inquiry that informed the analysis of qualified immunity before Harlow switched to an objective standard. See Keller, supra note 6, at 1390-91. But in cases from the nineteenth century such as Little and Mitchell, good faith does not shield an officer from liability for violation of law. Instead, bad faith can make unlawful an official act that would otherwise lie within the zone of discretion. See Little v. Barreme, 6 U.S. (2 Cranch) 170, 179 (1804); Merriam v. Mitchell, 13 Me. 439, 458 (1836).

67 See 161 U.S. 483, 498-99 (1896).

68 See Keller, supra note 6, at 1363-64.

69 See Spalding, 161 U.S. at 483 . For an account of the decision, see Pfander, supra note 37, at 36467.

70 Spalding, 161 U.S. at 484.

71 Id. at 486.

72 See id. at 498-99.

73 Id. at 499.
} 
Had the postal official invaded the plaintiff's common law interests, committing a positive government wrong, the matter may have been more complicated. As it was, the Spalding Court found no taking of property or defamation of character, but only an exercise of official discretion that cast new burdens on the plaintiff. ${ }^{74} \mathrm{Had}$ the plaintiff made out such tort claims, the Court would have faced the question from Wilkes $v$. Dinsman: whether Congress had conferred a zone of discretion within which a government official was empowered to commit what might otherwise constitute a common law tort (such as defamation or false imprisonment). ${ }^{75}$ Within that framework, Wilkes suggests that a showing of malice could change the result even where the official enjoyed some discretion. In short, rather than a common law immunity from liability based on the officer's good faith, the cases on which Keller relies consistently focus on the language of the operative statute and the scope of discretion it confers on the officer.

Given all that, one might ask where Keller locates the immunities from official liability to which he points. He begins by identifying absolute immunities for certain government officials, including legislators, judges, and high-ranking executive officials (presidents, governors). ${ }^{76}$ I have no quibble with those assertions; indeed, absolute legislative and judicial immunities survive in current law without serious controversy. ${ }^{77}$ Keller then argues that rank-and-file executive branch officials also received a form of qualified immunity comparable to that conferred on those officers today. ${ }^{78}$ But in doing so, Keller simply applies the label "qualified immunity" to a range of common law tort doctrines that either demanded a showing of malice by the plaintiff as a condition of recovery (such as the tort of malicious prosecution) or recognized that action taken within the official's zone of legislatively conferred discretion might violate the law if accompanied by malice or bad faith. ${ }^{79}$ In other words, rather than identify a

\footnotetext{
74 See id. at 498 (acknowledging that payments directly to clients, bypassing the attorney, would complicate the collection of fees but treating as evidently "clear" that such difficulties were not actionable).

75 See supra notes 60-66 and accompanying text.

76 See Keller, supra note 6, at 1355-58, 1360.

77 See generally Kilbourn v. Thompson, 103 U.S. 168 (1880) (recognizing legislative immunity); Stump v. Sparkman, 435 U.S. 349 (1978) (affirming judicial immunity). For an evaluation of Stump, arguing that the judge in question may have exceeded his jurisdiction, see JAMES E. PFANDER, PRINCIPLES OF FEDERAL JURISDICTION 273-74 (3d ed. 2017). I am puzzled, given Chief Justice Marshall's statement in Marbury v. Madison, 5 U.S. (1 Cranch) 137, 170 (1803), as to why Keller argues that cabinet officers were thought to enjoy some form of absolute immunity. See Keller, supra note 6, at 1360.

${ }^{78}$ Keller, supra note 6, at 1368.

${ }^{79} I d$. at 1374-75. On the elements of malicious prosecution, see MECHEM, supra note 32, at $\S 903$ (reciting elements of malicious prosecution as requiring plaintiff to show termination of prosecution in
} 
nineteenth-century body of law that qualifiedly immunizes executive officials who violated the rights of individuals, Keller has identified a collection of cases in which no violation was thought to occur.

Keller argues that the labels do not much matter, making it appropriate to treat decisions that denied relief on the merits as if they applied forms of "immunity." Throughout the paper, in keeping with this no-big-deal approach, Keller interpolates the language of qualified immunity into descriptions of doctrines that prevented the imposition of liability on other grounds. In justifying such interpolations, Keller points in a footnote to four nineteenth-century treatises-Cooley, Bishop, Mechem, and Throop. ${ }^{80}$ Keller tells us that these treatises use "interchangeable labels" such as "exemption from liability" and "immunity from civil action" to describe forms of official immunity. ${ }^{81}$ Notably, however, the quoted sections of the treatises discuss only the immunity doctrines applicable to legislators and judges and do not use the terms interchangeably to describe executive officers' immunity ${ }^{82}$ For example, Keller quotes sections 709 and 713 of the Throop treatise, which use the terms "no liability" and "immunity" to discuss suits against certain officials. But when we examine the quoted sections, we learn that section 709 deals with legislators and section 713 deals with judges. ${ }^{83}$

The same pattern recurs in Keller's use of the other treatises. Thus, Keller quotes section 376 of Cooley, which deals with legislators; ${ }^{84}$ sections 777 and 781 of Bishop (legislators and judges, respectively); ${ }^{85}$ and sections 621 and 638 of Mechem (judges). ${ }^{86}$ The absolute immunity these officials enjoyed was categorically absent from the treatment accorded executive

plaintiff's favor, lack of probable cause, and malicious motives). On the role of malice in taking official action outside an otherwise applicable zone of discretion, see the discussion of Wilkes v. Dinsman, supra note 60 .

${ }^{80}$ See Keller, supra note 6, at 1345 n.43 (citing ThOMAS M. COOLEy, A TREATISE ON THE LAW OF TORTS OR THE WRONGS WHICH ARISE INDEPENDENT OF CONTRACT 376 (1879); JOEL PRENTISS Bishop, COMMENTARIES ON THE NON-CONTRACT LAW AND ESPECIALly AS TO COMMON AFFaIRS Not OF CONTRACT OR THE EVERY-DAY RIGHTS AND TORTS $\$ \S 777,781$ (1889); MECHEM, supra note 32, $\S \S 621,638$; MONTGOMERY H. THROOP, A TREATISE ON THE LAW RELATING TO PUbliC OFFICERS AND SURETIES IN OFFICIAL BONDS $\S \S 709,713$ (1892)).

81 See Keller, supra note 6, at 1345 n. 43 .

82 See id. (citing COOLEY, supra note 80, at 376 (discussing immunity of legislators); BISHOP, supra note $80, \S \S 777,781$ (discussing immunities for legislators and judges respectively); MECHEM, supra note $32, \S \S 621,638$ (discussing immunities for judges and quasi-judicial officers respectively); THROOP, supra note $80, \S \S 709,713$ (discussing immunities for legislative and judicial and quasi-judicial acts respectively)).

83 THROOP, supra note $80, \S \S 709,713$.

84 COOLEY, supra note 80 , at 376.

85 BisHOP, supra note $80, \S \S 777,781$.

86 MECHEM, supra note 32, $\S \S 621,638$. 
officials, a conclusion Keller's own treatises confirm. Thus, in a discussion that Keller does not quote, section 712 of the Throop treatise explains that "executive officers ... are liable to private actions for misconduct." 87 In short, from the evidence Keller puts forward, it appears that nineteenthcentury treatise writers took the position that only legislators and judgesand perhaps some high-ranking executive officers, such as presidents and governors-enjoyed what was understood as an immunity from suit. Otherwise, executive officials were subject to liability when they violated the law (although the law, as we have seen, might confer discretion on the officers in some instances).

Here's why Keller's choices matter. Plaintiffs today claiming that they were subjected to, say, a seizure in violation of the Fourth Amendment must show that police officers used force that was objectively unreasonable. ${ }^{88}$ As elaborated in Graham v. Connor, the "'reasonableness' of a particular use of force must be judged from the perspective of a reasonable officer on the scene ... [taking account of] circumstances that are tense, uncertain, and rapidly evolving." ${ }^{\circ 9}$ Even where the plaintiff has successfully established the elements of a viable claim on the merits, the officer may nonetheless avoid liability by invoking the qualified immunity defense. Keller treats nineteenth-century cases where courts factored in reasonableness and good faith into their decisions on the merits as if they were recognizing a qualified immunity from suit. But qualified immunity goes beyond the liability rule. It affords the officer wholesale protection from liability for unconstitutional conduct unless the plaintiff can furnish evidence of the existence of prior "clearly established" law..$^{90}$

Keller does not defend the clearly established law standard as such by reference to nineteenth-century developments. But however formulated, modern immunity doctrine departs from its supposed nineteenth-century precursors in four important ways. First, as with any objective standard, like the clearly established law standard, qualified immunity assigns the lower federal courts primary responsibility for protecting officers from undue personal liability. In doing so, instead of sending close cases to the jury for resolution, as courts did in the nineteenth century, modern courts keep close

87 See THROOP, supra note $80, \S 712$.

88 See Graham v. Connor, 490 U.S. 386, 395 (1989).

${ }^{89}$ Id. at 396-97. Will Baude makes a similar point, observing that modern debates focus on the qualified immunity of law enforcement officers, who clearly lacked any qualified immunity in the nineteenth century. See Baude, supra note 7, at 4-5.

90 Joanna C. Schwartz, Qualified Immunity's Boldest Lie, 88 U. CHI. L. REv. 605, 618 (2021). On the challenges posed by the standard of clearly established law, see $i d$. at 613,618 (noting the difficulty of finding prior cases with nearly identical facts to meet the standard). 
cases away from the jury ${ }^{91}$ Second, modern qualified immunity applies to all constitutional tort claims for money damages, thus incorporating an acrossthe-board liability shield to all government activity. ${ }^{92}$ By contrast, the common law adopted a more nuanced approach, selectively incorporating inquiries into good faith and malice to take account of the specific claim at issue. ${ }^{93}$ In many instances, as with trespass, ejectment, and assumpsit liability, the officer's good faith was entirely irrelevant. ${ }^{94}$ Third, qualified immunity law puts the courts, rather than the political branches, in charge of fashioning protections and incentives for government officials. That sharply contrasts with nineteenth-century practice in which legislatures were responsible for shaping official incentives through salary and fee packages, legislative grants of official discretion, and the provision of indemnity to officers held liable for action taken in the line of duty. ${ }^{95}$ Fourth, modern-day qualified immunity applies to violations of constitutional norms, something for which (as the next Part makes clear) one finds no obvious nineteenthcentury analog.

\section{CONSTITUTIONAL LIMITS ON OFFICIAL DISCRETION}

Keller suggests either that the rules of qualified immunity may have applied to suits seeking damages for the violation of constitutional norms or that they were sensibly extended to constitutional tort litigation after Section

91 Compare Merriam v. Mitchell, 13 Me. 439, 458 (1836) (deferring to jury's award of damages against federal officer, notwithstanding officer's assertion of good faith as defense), with Harlow v. Fitzgerald, 457 U.S. 800, 818 (1982) (reformulating the immunity standard in objective terms to facilitate greater judicial control of suits against federal government officials).

92 See John C. Jeffries, Jr., Disaggregating Constitutional Torts, 110 YALE L.J. 259, 264 (2000) (describing qualified immunity as a comprehensive doctrine that applies across the board and does not take account of the specific duties of government officials).

93 As noted, malicious prosecution required a showing of malice. See supra notes 67-79 and accompanying text. In some cases, courts would imply malice from the deliberate character of the officer's actions in violating the plaintiff's rights. See Merriam, 13 Me. at 458.

${ }^{94}$ For trespass, see Little v. Barreme, 6 U.S. (2 Cranch) 170, 178-79 (1804); Merriam, 13 Me. at 442. For assumpsit, see Bartlett v. Kane, 57 U.S. (16 How.) 263, 272-73 (1854). For ejectment, see generally United States v. Lee, 106 U.S. 196 (1882).

95 For a discussion of official compensation and incentives, see generally NICHOLAS R. PARRILLO, Against the Profit Motive: The SAlary Revolution in American Government, 1780-1940 (2013) (describing a nineteenth-century world in which officers earned fees, salaries, and portions of the value of forfeited property, depending on the task at hand); $c f$. James E. Pfander, Judicial Compensation and the Definition of Judicial Power in the Early Republic, 107 Mich. L. REV. 1, 6 (2008) (describing the way salary-based judicial compensation incentivized courts of limited jurisdiction to reject new judicial business). On legislative control of discretion and indemnity, see supra notes 42-45, 52-66 and accompanying text. 
1983 became law in $1871 .{ }^{96}$ But the federal courts of the early republic do not appear to have conferred any immunity on defendant officials who committed positive government wrongs in violation of the Constitution. This Part of the Essay sketches the (immunity-free) model of constitutional litigation in the early republic and then steps back to evaluate the impact of constitutional limits on official discretion.

In the early nineteenth century, the Constitution operated less as a vehicle for direct assertion of constitutional claims than as a check on the authority claimed by government actors. ${ }^{97}$ The Constitution does not confer explicit rights to sue; it was framed on the assumption that the common law writ system was available to secure the enforcement of important constitutional rights. For example, the habeas non-suspension guarantee seemingly assumes the existence of a well-functioning writ and prohibits government suspensions except during times of rebellion or invasion. ${ }^{98}$ Similarly, the Due Process Clauses of the Fifth and Fourteenth Amendments do not empower individuals to sue, but they do impose due process limits on legislative denial of all effective rights to sue. ${ }^{99}$ Rather than providing for direct enforcement, then, the Constitution often came into play as a restriction on the authority defendant governments and their officers might claim in response to common law claims of various kinds. ${ }^{100}$

If less salient as a source of the right to sue, the Constitution nonetheless operated as a robust limit on the zone of official discretion lawfully conferred

\footnotetext{
96 See Keller, supra note 6, at 1344-45 (framing his article as offering evidence of a nineteenthcentury body of qualified immunity law that the Court might rightly draw upon in providing officials with a defense to liability under $\S 1983$ ).

97 See, e.g., Merriam, 13 Me. at 457 (treating reparation for false arrest as compelled by the "plainest dictates of common justice" rather than by constitutional compulsion). The right to sue was understood as an element of the common law. Consider two nineteenth-century decisions drawing on common law norms to fashion remedies against federal officers. Compare Crowell v. McFadon, 12 U.S. (8 Cranch) 94, 98 (1814) (rejecting owner's claim for conversion of cargo in connection with the lawful detention of a ship under the embargo act), with Slocum v. Mayberry, 15 U.S. (2 Wheat.) 1, 12-13 (1817) (allowing owner of ship detained under embargo act to replevy cargo out of the hands of officer).

98 See U.S. CONST. art. I, § 9, cl. 2. See generally TYLER, supra note 21, at 137-38 (acknowledging that one could read the habeas non-suspension clause to create an affirmative constitutional guarantee of federal habeas, but noting that Chief Justice Marshall interpreted the provision in Ex parte Bollman as one that only imposed constitutional limits on the exercise of habeas authority that had previously been conferred by written law).

99 See PFANDER, supra note 77, at 405-07.

100 See Richard H. Fallon, Jr., Constitutional Rights, Jurisdiction to Enforce Rights, and Entitlements to Remedies: An Exercise in Dialectic for the Twenty-First Century (forthcoming 2021) (manuscript at 32-43) (on file with author). For an account on constitutional tort claims before Bivens, see Carlos M. Vázquez \& Stephen I. Vladeck, State Law, the Westfall Act, and the Nature of the Bivens Question, 161 U. PA. L. REV. 509, 531-37 (2013) (describing what the authors call the "common law cause of action/federal defense" model of litigation in the nineteenth century).
} 
by statute. ${ }^{101}$ Consider, for example, the Court's approach to the litigation over the constitutionality of Ohio's decision to impose a tax on the Bank of the United States in Osborn v. Bank of the United States. ${ }^{102}$ State officials were authorized and directed to collect the tax and did so by levying distress on the property of the Bank. Distress, of course, had long been a recognized mode of tax collection; when individuals failed to pay the taxes owed, sheriffs and marshals were empowered to levy distress - that is, to seize and sell the taxpayer's property in satisfaction of the obligation. ${ }^{103}$ So long as the officials, both in imposing the tax and in levying on property to secure payment, stayed within the bounds of official discretion, their actions were lawful. But if the tax was invalid, the law did not properly authorize distress, or the officers strayed from their line of duty in levying distress, trespass remedies were available at common law. ${ }^{104}$

The Bank sued in trespass, arguing that Ohio lacked power under the Constitution to impose a tax on an instrumentality of the United States ${ }^{105}$ (as the Court had previously found in McCulloch v. Maryland). ${ }^{106}$ The Bank also sought injunctive relief, arguing that it was entitled to restrain what was in effect the destruction of its franchise by the taking of its property-an argument aided by the size of the tax levy and the difficulty of recovering money directly from state officials after it had been intermingled with other

101 With common law available to supply important remedies for government misconduct, the Constitution operated as a check on legislative interference with common law norms. In a recent defense of qualified immunity, Judge Oldham argues that a variety of statutes conferred forms of immunity on local officials including sheriffs, constables, and customs officials in seventeenth-century England. See generally Andrew S. Oldham, Official Immunity at the Founding (Apr. 12, 2021) (unpublished manuscript), https://papers.ssrn.com/a=3824983 [https://perma.cc/HA7Y-UYGW]. Oldham suggests that the Fourth Amendment took such developments on board, making room for the creation of official protections. Id. at 19. But in describing the provision of statutory immunities, Oldham tells us little about how the common law operates in the absence of any statutory intervention. See id. at 2-3. Critics of qualified immunity do not deny that Congress could write some forms of officer protection into positive law. $C f$. Owen v. City of Independence, 445 U.S. 622, 649 (1980) (recognizing a common law doctrine that "merely prevented courts from substituting their own judgment on matters within the lawful discretion of the municipality" but reaffirming that "a municipality has no 'discretion' to violate the Federal Constitution; its dictates are absolute and imperative").

10222 U.S. (9 Wheat.) 738 (1824). The relative dearth of similar suits affirmatively challenging the legality of state action may reflect the relative paucity of applicable rights. See, e.g., Barron v. Mayor of Baltimore, 32 U.S. (7 Pet.) 243, 250-51 (1833) (concluding that the Bill of Rights did not bind the states).

103 For the history of distress, see Den ex dem. Murray v. Hoboken Land \& Improvement Co., 59 U.S. (18 How.) 272, 284 (1855); Parrillo, supra note 51, at 93-95.

${ }^{104}$ For an account of nineteenth-century remedies for wrongful distress, see Pfander \& Borrasso, supra note 26 , at 20-22.

105 Osborn, 22 U.S. (9 Wheat.) at 739-40.

106 See McCulloch v. Maryland, 17 U.S. (4 Wheat.) 316, 437 (1819) (invalidating Maryland tax on the Bank of the United States as an instrumentality of the United States). 
assets in the state's treasury. ${ }^{107}$ The Ohio officials justified their actions by pointing to Ohio law and argued that they were entitled to levy distress to collect a lawful tax. ${ }^{108}$ The Court's reasoning ranged widely in the course of resolving the dispute but started with the proposition that if, as construed in McColluch, the Constitution invalidated the Ohio tax, it would deprive the officers of any lawful authority to levy distress on the Bank's property. ${ }^{109}$ Indeed, Ohio officials were reported to have "expressly waive[d] the extravagant proposition, that a void act can afford protection to the person who executes it," and had thus admitted they would, in such a case, face liability to the bank "to the extent of the injury sustained, in an action at law." "110 The Constitution thus set a limit to lawful official action, and officials who exceeded constitutional limits (however well-intentioned) were thought to enjoy no residual discretion within which to act lawfully or, in Keller's terms, no immunity from suit.

This approach to constitutional restrictions on the scope of lawful official authority was routinely applied throughout the nineteenth century. In a series of state court cases, officials were held liable in damages after the court concluded that the Constitution invalidated the authority under which they purported to act. ${ }^{111}$ As one court explained, "[n]o question in law is better settled ... than that ministerial officers and other persons are liable for acts done under an act of the legislature which is unconstitutional and void." 112 To be sure, some courts departed from this "settled" law, apparently on the doubtful basis that a justice of the peace enjoyed judicial immunity. ${ }^{113}$ Yet, the dominant rule remained one of liability for unconstitutional action, action taken pursuant to invalid legislative authority. As the quoted explanation above makes clear, the liability attaches to both ministerial and

107 Osborn, 22 U.S. (9 Wheat.) at 739 (describing the Bank's bill for a writ of injunction).

108 See id. at 836-37.

109 Id. at $867-68$.

110 Id. at 839.

111 See Fisher v. McGirr, 67 Mass. (1 Gray) 1, 51 (1854) (allowing damages against an officer for seizing, keeping, and destroying liquor under an unconstitutional law); Shanley v. Wells, 71 Ill. 78, 83 (1873) (allowing damages against an officer for an arrest pursuant to an unconstitutional vagrancy law); Campbell v. Sherman, 35 Wis. 103, 108 (1874) (allowing damages against an officer for seizing a steamboat pursuant to an unconstitutional law); Sumner v. Beeler, 50 Ind. 341, 342 (1875) (allowing damages for false arrest, imprisonment, prosecution, and harm under an unconstitutional act); Gross v. Rice, 71 Me. 241, 257-58 (1880) (allowing a prisoner's damages action against a warden who held him pursuant to an unconstitutional law); see also Woolsey v. Dodge, 30 F. Cas. 606, 609 (C.C.D. Ohio 1854) (No. 18,032) (declaring it unlawful to collect a tax that exceeds the government's constitutional authority).

112 Sumner, 50 Ind. at 342.

113 See Henke v. McCord, 7 N.W. 623, 625-26 (Iowa 1880) (affording immunity to the justice of the peace and the officer who seized property under the authority of an unconstitutional ordinance); see Baude, supra note 7, at 2 (describing the boundaries of quasi-judicial immunity as "shaggy"). 
"other" officers. Ohio state officials could not have evaded the controlling authority of federal constitutional law by invoking a body of state law that set up a zone of discretion for the taxation of the national Bank. ${ }^{114}$

The nineteenth century's emphasis on assured remediation - the notion expressed in Marbury that every right should have a remedy ${ }^{115}$-also influenced the common law's approach to absolute official immunity. Keller cites Cooley's treatise for the proposition that the governor enjoys absolute immunity in issuing pardons and reprieves, commanding the militia, and executing the law. ${ }^{116}$ All such actions would fall within the zone of executive discretion that Marbury described as off-limits to the courts. ${ }^{117}$ But suppose that a governor, in the course of commanding the militia and without any showing of necessity, directed his troops to occupy the farmstead of a state citizen or take the citizen's crop to feed his soldiers? Or suppose that the officers of the U.S. Army caused the arrest of citizens on suspicion of giving aid and comfort to the British during the War of 1812? In both instances, whatever immunity the commander-in-chief enjoys, suit would lie against the officials who carried out those orders, triggering a challenge to the orders' legality on the basis that they exceeded government power. ${ }^{118}$ Similarly, the absolute legislative immunity to which Keller refers ${ }^{119}$ meant that the assembly's sergeant-at-arms was liable (as an executive officer) for carrying out the assembly's orders to arrest and imprison individuals for

114 Keller sometimes questions this conclusion, suggesting that only ministerial officers faced liability for action taken on the basis of an invalid grant of authority. See Keller, supra note 6, at 1350 52 (characterizing a naval captain, incongruously, as a ministerial officer).

115 See Marbury v. Madison, 5 U.S. (1 Cranch) 137, 163 (1803) (describing as indisputable the rule that "where there is a legal right, there is also a legal remedy by suit or action at law, whenever that right is invaded") (internal quotation marks omitted) (quoting WILLIAM BLACKSTONE, 3 COMMENTARIES ON THE LAWS OF ENGLAND 23 (1768)).

116 See Keller, supra note 6, at 1365 (quoting COOLEY, supra note 80, at 377). Even so, the governor's ministerial duties "may be enforced by mandamus as in other cases." MECHEM, supra note $32, \S 610$.

117 See Marbury, 5 U.S. (1 Cranch) at 167-70 (reaffirming the importance of remedies for violations of private rights but recognizing that executive branch officials enjoy a measure of unreviewable official discretion); see also MECHEM, supra note 32, § 594 (describing the "pardoning power of the executive" as an example of unreviewable discretion; the "governor may, in his discretion, grant a pardon, but no one can have a legal right to be pardoned.... The law does not attempt by its process to control discretionary power").

118 See Pfander, supra note 25, at 754-55, 762-64 (describing successful legal challenges to military detention during the War of 1812 and to the taking of private property to support the troops during the Mexican-American War); see also Mitchell v. Harmony, 54 U.S. (13 How.) 115, 137 (1851) (holding that a colonel who expropriated a merchant's property for military use during the Mexican-American War was liable for trespass and could not invoke his superior's orders as a justification); Dow v. Johnson, 100 U.S. 158, 169 (1879) (reaffirming Mitchell).

119 See Keller, supra note 6, at 1355-57. 
contempt of Congress. ${ }^{120}$ In other words, absolute immunities (for presidents, governors, and legislators) did not always foreclose liability, but directed litigation towards the low-level officials charged with carrying their orders into effect. The warden who detains a prisoner on orders from the President, for example, must account to the court on habeas for the legality of such imprisonment. As to such low-level officers, no immunity (qualified or otherwise) was thought to apply.

\section{CONCLUSION}

Today, administrative law duplicates the nineteenth-century dispensation to a certain degree. Agencies enjoy discretion, conferred by Congress, within which they formulate rules and adjudicate disputes free from exacting judicial oversight. ${ }^{121}$ But reviewing courts continue to evaluate agency action for compliance with law, including the law of the Constitution. In Crowell v. Benson, the opinion that structures review of agency action, the Court sought to preserve federal judicial review of issues of law and some issues of constitutional and jurisdictional fact, apparently in an effort to preserve the boundary-enforcing role that common law courts had performed throughout the nineteenth century. ${ }^{122}$ Then as now, agency decisions may be invalidated if they exceed the limits of official discretion, lawfully conferred, under the judicial review provisions of the Administrative Procedure Act. ${ }^{123}$ But modern law handles positive government wrongs separately. Claims seeking redress for the torts of federal officers proceed under the Federal Tort Claims Act (with zones of discretion but no qualified immunity), ${ }^{124}$ and constitutional tort claims against federal officers proceed under the Bivens doctrine. ${ }^{125}$

\footnotetext{
120 See Kilbourn v. Thompson, 103 U.S. 168, 196-97, 200 (1881) (recognizing legislative immunity but confirming that the assembly's sergeant-at-arms bore responsibility in tort for trespass or false arrest).

121 See generally Harvey Saferstein, Nonreviewability: A Functional Analysis of "Committed to Agency Discretion," 82 HARV. L. REV. 367 (1968) (discussing situations in which agencies exercise unreviewable discretion); Martin Shapiro, Administrative Discretion: The Next Stage, 92 YALE L.J. 1487, 1490 (1983) (noting that the Administrative Procedure Act prohibits review of actions "committed to agency discretion" but acknowledging that courts have understood the provision to apply only when they find no law to apply).

122 See Crowell v. Benson, 285 U.S. 22, 57-61 (1932).

123 See Administrative Procedure Act, 5 U.S.C. $§ 706(2)$ (authorizing courts to set aside agency action found to be "(A) arbitrary, capricious, an abuse of discretion, or otherwise not in accordance with law; (B) contrary to constitutional right, power, privilege, or immunity; (C) in excess of statutory jurisdiction, authority, or limitations").

124 On the right of individuals to seek compensation for the torts of federal officers, see 28 U.S.C. $\S \S 1346$ (b), 2671-2680. For the discretionary function exception, see 28 U.S.C. § 2680(a).

125 For an overview of the Bivens doctrine, imposing personal liability on federal officials who commit constitutional torts, see generally James E. Pfander, Alexander A. Reinert \& Joanna C. Schwartz, The Myth of Personal Liability: Who Pays When Bivens Claims Succeed, 72 Stan. L. Rev. 561 (2020).
} 
The debate over qualified immunity centers on the legitimacy of its recognition as a defense to claims under Section 1983 and Bivens for positive government wrongs, committed in violation of constitutional limits by law enforcement officers, both state and federal. In the early republic, as we have seen, constitutional law restricted the zone of lawful discretion, and government officials were held personally liable for the positive government wrongs they committed in exceeding the authority so limited. Departing from this common law backdrop, the modern Supreme Court, in its qualified immunity jurisprudence, has created a judge-made immunity that gives officials discretionary authority to violate the Constitution. Critics and defenders of the doctrine have had much to say. But, in contrast to the message Keller seeks to convey, one has difficulty locating a discretionary power to violate the Constitution in the decisional law of the nineteenth century. 